\title{
Eğitim Fakültesi Temel Eğitim Bölümü Öğretmen Adaylarının İlk Yardım Bilgi Düzeylerinin İncelenmesi
}

\author{
Asiye Parlak Rakap ${ }^{* *}$, Fatma Erkoç², Özlem Eda Çakar³ \\ ${ }^{1}$ Van Yüzüncü Yıl Üniversitesi, Eğitim Fakültesi Okul Öncesi Eğitimi ABD, Van Türkiye \\ ${ }^{2,3}$ Milli Eğitim Bakanlığı, Ankara, Türkiye \\ ORCID: A. Parlak-Rakap (0000-0001-8315-8628), F. Erkoç (0000-0003-1392-5283), Ö.E. Çakar(0000-0002-3579-220X)
}

\begin{abstract}
Özet
Bu araștırmanın amacı, Eğitim Fakültesine devam eden Temel Eğitim Bölümü öğretmen adaylarının ilk yardım bilgi düzeylerini değerlendirmektir. Çalışmada tarama yöntemi kullanılmıştır. Araştırma örnekleminde Doğu Anadolu Bölgesi'ndeki bir büyükşehirde yer alan bir üniversitenin Temel Eğitim Bölümü öğrencisi 423 öğretmen adayına ulaşılmıştır. Verilerin toplanmasında Temel ilk Yardım Uygulamalarına İlişkin Bilgi Düzeyi anket formu kullanılmıştır. İlk yardım bilgisi ile dört gruplu sınıf değişkeni arasındaki etki için tek yönlü ANOVA ve ilk yardım bilgisi ile iki gruplu anabilim dalı, iki gruplu ders alma, iki gruplu eğitim alma değişkenleri arasındaki etki için ise t-testi kullanılmıştır. Analiz sonucunda elde edilen bulgular, öğretmen adaylarının ilk yardım hakkında sahip oldukları bilgilerinde anabilim dalı ve sınıfın etkili olmamasına karşın ilk yardım dersi ve ilk yardım eğitimi almanın etkisi olduğunu göstermektedir. Bulgular literatürle değerlendirildiğinde benzer sonuçlar ortaya çıkmaktadır. Öğretmen eğitimi programlarının uygulamalı ilk yardım eğitimi verme bakımından güncellenmesi önerilmektedir.
\end{abstract}

Anahtar Kelimeler: Temel Eğitim Bölümü Öğretmen Adayları, İlk Yardım Bilgi Düzeyi, Okul Sağlığı ve Güvenliği.

\section{Analyzing First Aid Knowledge Levels of Teacher Candidates Studying at Department of Elementary Teacher Education}

\begin{abstract}
Purpose of the current research was to evaluate the first aid knowledge level of elementary grades teacher candidates who were studying at the Faculty of Education in a university located in a metropolitan city in the Eastern Anatolia. The screening method was used. 423 teacher candidates from the Department of Elementary Teacher Education of a university located in a metropolitan city in the Eastern Anatolia were reached by using convenient sampling method. The Knowledge Level on Basic First Aid Practices Questionnaire was used for data collection. Data were evaluated statistically by using One-way ANOVA and t-test. According to findings, although program and grade level were not of any effect, taken-a-first aid course and taken-a-first aid training had effect on the knowledge level. Similar results emerged when findings were evaluated with literature. It is recommended that teacher training programs should be updated in terms of providing practical first aid training.
\end{abstract}

Keywords: Department of Elementary Teacher Education Teacher Candidates, First Aid Knowledge Level, School Health and Safety

\section{GIRIŞ}

1960lı yılların başından itibaren, ekipmansız harici kardiyopulmoner resüsitasyon (KPR) temel yaşam desteği (TYD) eğitimi, yani A (hava yolu kontrolü) -B (ağızdan ağza solunum) -C (göğüs (kalp) kompresyonları), öncelikle tıbbi personele ve sonrasında tıbbi personel harici kişilere mankenler üzerinde verilmeye başlamıştır. Bu gelişmeyle birlikte, tıbbi personel harici kişilerin TYD becerileri kazanmaları ve bunları kullanmalarına yardımcı olmayı amaçlayan eğitim araştırmalarına odaklanılmıştır (Eisenburger ve Safar, 1999, Safar vd.,

\footnotetext{
*Yazışma Adresi / Address for Correspondence:

A. Parlak-Rakap, Email: asiye.parlak@gmail.com

Geliş Tarihi / Received Date: 04.03 .2021

Kabul Tarihi / Accepted Date: 04.05.2021

Doi: $10.32329 /$ uad. 891305
}

1981). TYD, Hayat Kurtarma Zinciri ve temel ilkyardım uygulaması olarak bilinen becerilerdir. Hayat Kurtarma Zinciri, hastayı terk etmeden ambulans çağırma, KPRTYD aşamaları (A-B-C), dış kanama kontrolü ve şok-bilinçsizlik (koma) için konumlandırma gibi temel ilkyardım uygulamalarını içermektedir. Temel ilkyardım uygulamaları, koruma, bildirme ve kurtarmayı kapsamaktadır (Akalın vd., 2008). Görüldüğü üzere ilkyardım, kaza, yaralanma gibi yaşamı tehlikeye düşüren durumlarda sağlık görevlileri gelene kadar hayat kurtarma ya da durumun kötüye gidişinin engellenmesinde en önemli olan ilk müdahaledir (Abelairas-Gómez vd., 2020; Bollig, Wahlc ve Svendsend, 2009). Olay yerinde ve herhangi bir tıbbi araç kullanılmadan var olan araçlarla yapılır. İlk yardımın temel amacı hayat kurtarmadır ve bu amaca ulaşmak için hayati tehlikenin ortadan kaldırılması, yaşamsal fonksiyonların sürdürülmesinin sağlanması, 
hasta veya yaralının durumunun kötüleşmesinin önlenmesi ve iyileşmesinin kolaylaştırılması gerekmektedir (Umur, 2012). Bu uygulamaların, bazen bir çocuğun ilk yardıma ihtiyacı varken bazen de ilk yardıma ihtiyacı olan bir yetişkinin yanında bir çocuk olması nedeniyle, 10 yaşından itibaren bütün bireylere eğitim yoluyla kazandırılması önemli görülmektedir (Bollig, Wahlc ve Svendsend, 2009).

Yaş ve gelişim düzeyleri sebebiyle çocukların kazaya uğrama riski yetişkinlerden yüksektir. Her ne kadar gelişimde izlenen ortak bazı kilometre taşları olsa da kabul edilen gerçek, her çocuğun gelişiminin birbirinden farklı oluşudur (Brazelton, 1992). Bilişsel, davranışsal ve fiziksel, bütün gelişim alanlarında görülen bu farklılıklar, kaza geçirme-yaralanma konusunda çocukların daha yüksek oranda risk grubunda olmalarına sebep olmaktadır. Bir- üç yaş arası görülen emekleme-yürüme gibi mobil hareketler ve çocuklarda artan hareket yeteneğiyle paralel olarak öğrenme ve araştırma merakı da artmaktadır. Ancak okul öncesi dönemden itibaren yeni yeni gelişmeye başlayan davranışsal öz-düzenleme ve öz kontrol becerileri, görme ve işitme alanlarının yeterince gelişmemiş olması gibi birçok nedenden dolayı bu yaş grubunda kaza ve yaralanmalar daha sık görülmektedir. Her ne kadar çocukların gelişimsel açıdan farklı oldukları çocuğu koruma sorumluluğu olan yetişkinler tarafından kabul edilse de, farklılığı daha çok mizaç, bilişsel, sosyal ve duygusal alanlarla sınırlı ele almakta ve çocuk sağlığına yeterince önem vermeyebilmektedirler. Dolayısıyla, çocuklarda bedensel olarak sağlıklı iyi olma halini birincil olarak ilgili mesleki kurum ve kişilere atfetmekte, çocukları yaralanmalardan koruma bilinci geliştirememektedirler. Ve ne yazık ki çocuklarda görülen kaza ve yaralanmaların riski de artmaktadır (Uğur Baysal vd., 2005). Öncelikle çocuğun bakımından birinci derecede sorumlu olan yetişkinler (ebeveynler, vb.) olmak üzere çocuğun bakımını ve eğitimini üstlenen bireylerin kaza risklerini bilme, öngörme ve kazalardan korunma farkındalıkları çocukların kazalardan ve yaralanmalardan korunmasında belirleyicidir (Öz, 2010).

Yaralanma sıklığı, yaş aralığ 1 , yaralanma bölgeleri ve yaralanma nedenlerine bakıldığında, yaralanmaların büyük bir kısmının evde meydana geldiği görülmüştür. Evde yaralanmaların temel sebebi çocukluğun ilk yıllarında yatak/kanepeden düşme ya da ebeveynin çocuğu kazayla düşürmesi olarak görülmüştür. Ergenlik dönemi ev kazalarında ise ergen sakarlığından kaynaklanan yaralanmaların meydana geldiği saptanmıştır. Travmatik yaralanmaların sıklıkla 7-10 yaş arasında meydana geldiği, 12 yaş sonrasında ise yaralanmaların sayıca yüksek seyrettiği gözlemlenmiştir. İlk altı yaşa kadar dirsek yaralanmaları, 3 yaş grubunda genel olarak kız çocuklarında görülen ağrılı pronasyon yaralanmaları, 7-11 yaşlarında el bileği ve el yaralanmaları ve 12 yaş üzerinde ise el bileği yaralanmaları, yaşlara göre dağılımda en sık yaralanan bölgelerdir (Bombacı vd., 2008). Çocuk yaralanmaları evde, parkta, su kenarında, tarım alanlarında, sokakta ve okulda, kısaca herhangi bir yerde veya her yerde gerçekleşebilmektedir. Türkiye'de ev kazaları \%25 oranında görülmektedir ve trafik kazalarından sonra ikinci sırada yer almaktadır. Bu kazaların çoğunun, çocuk, bir yetişkinin yanındayken gerçekleştiği göz önüne alındığında çocukların kaza geçirmelerinin ve yaralanmalarının önlenmesi önemli bir görev olarak karşımıza çıkmaktadır ve bu görevden yetişkinler sorumlu tutulmaktadır (Halk Sağlığ Genel Müdürlüğü, 2019). Buna ek olarak, dünyada her yıl 10 çocuktan biri okulda yaşanan kazalar nedeniyle sağlık kuruluşuna başvurmaktadır. Birçok ülkede bu yaş grubundaki çocuk ölümlerinin birinci nedeni okul çağında ortaya çıkan kazalardır. Öğretmenlerin ya da okuldaki görevlilerin ilk yardım uygulamaları sayesinde bu oranın düşebileceği öngörülmekle birlikte, Türkiye'de de durum farksız değildir (Türkiye İstatistik Kurumu, 2017). TÜİK 2019 verilerine göre 0-14 yaş arası çocuklarda en yüksek ölüm nedeni dışsal yaralanmalar ve zehirlenmelerdir (TÜİK, 2020a). Ölüm, yaralanmaların görünen bir yüzüdür. Diğer taraftan, çocuğun yaşamı süresince kısa ya da uzun süreli etkiler bırakabilmektedir. Bu etkiler, tedavi amacıyla acil servise başvurma, hatta uzun süreli hastane bakımı, sürekli engellilik, yas gibi duygusal sorunlar, vb. çeşitli bir yelpazede yer alabilmektedir (Uğur Baysal, Yıldırım ve Bulut, 2005).

Okullarda meydana gelebilecek kazalar ve yaralanmalara ilk müdahalede bulunacak kişi olarak öğretmenlerin ilk yardım bilgilerini ölçmek, karşılaştıkları sorunları ve ilk yardım ile ilgili yapılacak eğitimlere karşı tutumlarını belirlemek önemlidir. Bu amaçla yapılan bir çalışmada 364 ilkokul ve lise öğretmenine ulaşılmıştır. Sınıf öğretmeni, Sosyal Bilgiler, Yabancı Dil, Meslek dersi, Matematik, Fen Bilimleri ve Türkçe öğretmenleriyle yürütülen bu çalışmada kadın öğretmenlerin bilgi düzeylerinin erkek öğretmenlerin bilgi düzeylerinden ve ilköğretim öğretmenlerinin bilgi düzeylerinin lise öğretmenlerinden daha yüksek olduğu bulunmuştur. Çalışma bulgularına göre en az yanlıș cevaplandırılan konular sırası ile yanıklı hastaya, asidik ya da bazik madde yutmuş hastaya ve burun kanaması olan hastaya yapılan müdahaledir. Okullarda en sık karşılaşılan durumların ise kanama $(\% 51,6)$, bayılma (\%33) ve kırık-çıkık $(\% 12,9)$ olduğu görülmüştür. Diğer bir bulgu ise, öğretmenlerin çoğunun ilk yardım konusunda bilgi düzeyleri yetersiz olsa da ilk yardım eğitimlerine istekli olmalarıdır (Nayir vd., 2011). Benzer bir çalışma, üç farklı fakültenin öğrencileriyle bir üniversitede yürütülmüştür (Özçelikay, Şimşek ve Asil, 1996). Üniversite öğrencilerinin ilk yardım bilgisini tespit etmek için yapılan bu çalışmada ise Eğitim, Fen ve Eczacılık öğrencilerinin ilk yardım eğitimi hakkındaki düşünceleri alınmıştır. Sonuç olarak, öğrencilerin \%71'inin ilk yardım üzerine eğitim verilmesi gerektiğini belirttikleri görülmüştür. Kıbrıs'ta öğretmen adaylarıyla yapılan bir araştırmada ise (Özer, 2018) ilk yardım uygulamalarının bilen biri tarafından uygulandığında hayat kurtardığı; 
bununla birlikte yanlış müdahalelerin olumsuz sonuçlar doğurduğu vurgulanmıștır. Eğitim Fakültesinin ilk iki sınıfına devam eden öğrencilerin ilk yardım bilgisi puanlarının, son iki sınıftakilere göre daha düşük olduğu; katılım gösteren öğrencilerin ilk yardım konusundaki önermelere genellikle doğru cevaplar vermiş olsalar da verdikleri yanlış cevapların da yüksek olduğu görülmüştür. Özer bu çalışmasının sonucunda, öğretmenlerin ilk yardım konusunda bilgili olmaları gerektiğine; bu nedenle öğretmenlerin hizmet öncesinde ilk yardım konusundaki bilgi ve beceri düzeylerinin artırılmasına yönelik uygulamalara katılmasının önemli olduğu sonucuna ulaşmıştır.

İlk yardım konusunda temel eğitim öğretmenleri ve öğretmen adaylarıyla yapılmış araştırmalar incelendiğinde her iki çalışma grubuna yönelik farklı sonuçlar göze çarpmaktadır. Okul öncesi öğretmenlerinin \%16,7'sinin ilk yardım konusunda kendini yeterli gördüğünün tespit edildiği Dinçer ve Atakurt (2000)'un çalışmasının yanında Erkan ve Göz (2006) ilkokulda görev yapan öğretmenlerin \%68,4 ünün daha önce ilk yardım eğitimi almadıklarını aktarmışlardır. Dinçer ve Atakurt'un (2000) diğer bir bulgusu ise üniversite mezunu öğretmenlerin lise mezunu öğretmenlerden daha doğru bilgi verdikleridir. Erkan ve Göz'ün (2006) yaptığı çalışmada ise sınıf öğretmenlerinin epilepsi, suni solunum, kalp masajı hakkında bilgi sahibi olmadıkları; branş öğretmenlerinin ise şok, suni solunum ve kalp masajı konusunda yetersiz bilgiye sahip oldukları görülmüştür. Alanyazında yer alan çalışmalar incelendiğinde ilk yardımın önemli olduğu ancak öğretmenler ve öğretmen adaylarının ilk yardım bilgilerinin sınırlı ve aldıkları eğitimi yetersiz buldukları ortaya çıkmıştır (Dinçer vd., 2000; Nayir vd., 2011; Özçelikay vd., 1996; Özer, 2018).

Türkiye İstatistik Kurumu 2020 (2020b) yılı verilerine göre Türkiye'de Adrese Dayalı Nüfus Kayıt Sistemine göre 22.750.657 çocuk vardır ve bu sayının toplam nüfusa oranı \% 27,2' dir. Çocuk nüfusunun \% 8,9'u (2.026.469 çocuk) ise Doğu Anadolu Bölgesi'nde ikamet etmektedir. Literatürde Doğu Anadolu Bölgesi'nde temel eğitim kademesinde görev yapan öğretmenler ya da görev yapma ihtimali olan öğretmen adaylarının ilk yardım bilgi düzeylerine yönelik yapılmış bir araştırmaya rastlanmamıştır. Bu nedenle, bu çalışmanın amacı Doğu Anadolu Bölgesi'ndeki bir üniversitede eğitim gören Temel Eğitim bölümü öğrencilerinin ilk yardım konusundaki bilgi düzeylerini bazı değişkenler açısından belirlemektir. Bu amaçla ilgili alt amaçlar ise şöyledir:

- Temel Eğitim bölümü öğrencilerinin ilk yardım konusundaki bilgi düzeyleri okudukları anabilim dalına göre istatistiksel açıdan anlamlı bir farklılık göstermekte midir?

- Temel Eğitim bölümü öğrencilerinin ilk yardım konusundaki bilgi düzeyleri okudukları sınıfa göre istatistiksel açıdan anlamlı bir farklılık göstermekte midir?

- Temel Eğitim bölümü öğrencilerinin ilk yardım konusundaki bilgi düzeyleri ilk yardım dersi alma durumlarına göre istatistiksel açıdan anlamlı bir farklılık göstermekte midir?

- Temel Eğitim bölümü öğrencilerinin ilk yardım konusundaki bilgi düzeyleri daha önce herhangi bir ilk yardım eğitimine katılım durumuna göre istatistiksel açıdan anlamlı bir farklılık göstermekte midir?

\section{YÖNTEM}

Amaç ve alt amaçlarla bağlantılı olarak çalışmada Nicel Araştırma deseninden tarama yöntemi kullanılmıştır. Tarama yöntemi eğitim bilimlerinde en sık kullanılan bir desen olarak karşımıza çıkmaktadır. Tarama deseni, eğitim bileşenleri üzerinde sadece öğrenmenin gerçekleştiği ana değil onların üzerindeki çok çeşitli olguları sorgulayan bir özelliğe sahiptir (Fazlığulları ve Kurul, 2012). Tarama araştırmalarının amacı araştırma konusunda var olan durumu fotoğraflarcasına betimleme yapmaktır. Onları değiştirme veya etkileme çabası gösterilmez. Grup üzerinde yapılan çalışma ve sonuçlar evrene genellenebilmektedir (Çatak, 2014).

\section{1. Çalışma grubu}

Çalışmanın evreni Doğu Anadolu Bölgesinde bir büyükşehirde yer alan bir üniversitenin Eğitim Fakültesi bünyesindeki Temel Eğitim Bölümü öğrencileridir. Örneklemde ise hem ulaşılabilirliği hem de uygunluğu açısından bölgedeki bir üniversitede öğrenim görmekte olan Temel Eğitim Bölümü öğretmen adaylarından gönüllü olanlar katılımcı olarak yer almaktadır. Veri toplama sürecinde 423 kişiye ulaşılmış, veri analizi öncesi yapılan veri temizliğinde hep aynı seçeneğin cevaplandığı ve bazı soruların cevaplanmadığı 11 veri çıkarılmış ve 412 verinin analizi yapılmıştır. Katılımcıların 211'i Okul Öncesi Öğretmenliğinde, 201'i ise Sınıf Öğretmenliğinde; 90’1 birinci, 101'i ikinci, 105'i üçüncü ve 116’sı son sınıfta okumaktadır. 284'ü daha önce öğrenim gördükleri lisans programında ilk yardım dersi aldığını belirtirken 128'i almadığını; 261'i herhangi bir kurum aracılığıyla ilk yardım eğitimi aldığını beyan ederken 151’i almadığını bildirmiştir.

\subsection{Veri Toplama Aracı}

Araştırmada, Sönmez, Uskun ve Pehlivan (2014) tarafından geliştirilen Temel İlk Yardım Uygulamalarına İlişkin Bilgi Düzeyi anket formu yazarlardan izin alındıktan sonra katılımda gönüllülük esasına dayanarak uygulanmıştır. Veri toplama süreci, öğretmen adaylarının ilk yardım konusundaki bilgi düzeylerini belirlemek için aynı zaman dilimi içerisinde (araya zaman faktörü girmeden) ve tek seferde gerçekleştirilmiştir. Ankette ilk yardım ile ilgili boşluk doldurma (iki soru), çoktan seçmeli (beş soru), doğru/yanlış (13 soru) olmak üzere 20 bilgi sorusu ve demografik bilgilerle ilgili sorular yer almak- 
tadır. Bilgi sorularından biri "Burkulmalarda, burkulan organ istirahate alınarak soğuk uygulama yapılmalıdır"dir. Her doğru yanıtlanan soru 1 puandır ve alınabilecek en düşük puan 0'ken en yüksek puan 20'dir. Demografik bilgi formunda ise katılımcının öğrenim gördüğü anabilim dalı, sınıfı, öğrenim gördüğü lisans programında ilk yardım konusunda bir ders ve herhangi bir kurumdan ilk yardım eğitimi alıp almadığı sorulmuştur.

\subsection{Veri Toplama Süreci}

Okul Öncesi Öğretmenliği ve Sınıf Öğretmenliği anabilim dallarının her sınıfında öğrenim görmekte olan öğretmen adaylarına anketler verilmiș ve tamamlamaları beklenmiş, tamamladıktan sonra da toplanmıştır. Fakültenin duyurulan ders programı aracilığıyla anketlerin uygulanabileceği uygun gün ve ders saatleri belirlenerek dersi yürüten öğretim elemanlarılya iletişime geçilmiş; öğretim elemanlarının onayıyla anketler uygulanmıștır. Anketlerle ilgili olarak gruba bilgilendirme yapılmış ve uygulama sonrasında ankette yer alan merak ettikleri sorular hakkında iletişime geçilmiştir. Veri toplama süreci, her ne kadar yüzyüze yapılması planlansa da, 2020 yılı Mart ayında ülkemizi de etkisi altına alan salgın sebebiyle çevrimiçi yürütülmüștür.

\subsection{Veri Analizi}

Veriler SPSS programına kaydedilmiștir. Parametrik testlerin en temel varsayımı olan normallik testi uygulanmış ve verilerin normal dağılım gösterdiği bulunmuştur. İlk yardım bilgisi ile sınıf değișkeni (dört gruplu) arasındaki etkiyi görmek amaciyla parametrik bir test olan tek yönlü ANOVA; ilk yardım bilgisi ile anabilim dalı (iki gruplu), ders alma (iki gruplu) ve eğitim alma (iki gruplu) değişkenleri arasındaki etkiyi görmek için ise t-testi kullanılmıştır. İstatistiksel anlamlılıkta çalışmadaki sınır değer $\mathrm{p}<0,05$ 'tir.

\subsection{Etik}

Bu çalışmada hem ulusal hem de uluslararası bağlamda beklenen etik kurallara uyulmuştur. Araştırma için etik kurul çalışma onayı Van Yüzüncü Yll Üniversitesi
Rektörlüğü Sosyal ve Beșeri Bilimleri Etik Kurulu’ndan 16/11/2020 tarih ve 2020/13-01 sayılı kararıyla alınmıştir.

\section{BULGULAR}

Temel Eğitim bölümü öğrencilerinin ilk yardım konusundaki bilgi düzeylerinin okudukları anabilim dalına, okudukları sınıfa, ilk yardım dersi alma durumlarına ve daha önce herhangi bir ilk yardım eğitimine katılım durumuna göre farklılık gösterip gösterilmediğinin araştırıldığı bu çalışmada bulgular ANOVA ve T-testi sonucunda elde edilmiştir.

Sınıf düzeyinin ilk yardım bilgisi üzerinde bir etkisinin olup olmadığını test etmek için uygulanan tek yönlü ANOVA sonucunda, sınıfın (1.,2.,3. veya 4. sınıf) ilk yardım bilgisinde istatistiksel açıdan anlamlı bir etkisi olmadığı $(F(3,408)=11,12, p>0,05)$ görülmüştür (bkz. Tablo 1).

Tablo 1. Sınıf düzeyi ve ilk yardım bilgilerinin incelenmesi

\begin{tabular}{|c|c|c|c|c|c|}
\hline \multicolumn{7}{|c|}{ ANOVA } \\
\hline & KT & SD & KO & F & P \\
\hline Gruplar Arası & 33,589 & 3 & 11,196 & 1,266 &, 286 \\
\hline Gruplar İçi & 3608,496 & 408 & 8,844 & & \\
\hline Toplam & 3642,085 & 411 & & & \\
\hline
\end{tabular}

Okul Öncesi Öğretmenliği ya da Sınıf Öğretmenliğinde öğrenim görmeninilkyardım bilgisi üzerindebir etkisinin olup olmadığını analiz etmek için bağımsız örneklemler t-testi uygulanmıștır. Analiz sonucunda, Okul Öncesi Öğretmenliği $(X=19,13, S S=2,73)$ ve Sinıf Öğretmenliği $(\mathrm{X}=19,09, \quad \mathrm{SS}=3,2) \quad$ grupları arasında istatistiksel olarak anlamlı bir fark bulunamamıştır $(\mathrm{t}(392,4)=0,16$, $\mathrm{p}=0$. 870). Bu sonuçlara göre, Okul Öncesi Öğretmenliğindeki katılımcıların ilk yardım bilgi düzeyleri Sınıf Öğretmenliğindeki katılımcıların ilk yardım bilgi düzeylerine göre daha pozitif olmasına rağmen fark, istatistiksel olarak anlamlı değildir (bkz. Tablo 2).

Lisans programında ilk yardım dersi alma ya da alma-

Tablo 2. Okul Öncesi ve Sınıf Öğretmenliği ilk yardım bilgilerinin incelenmesi

\begin{tabular}{|c|c|c|c|c|c|c|c|c|c|c|}
\hline \multicolumn{11}{|c|}{ Bağımsız Örneklemler için T Testi } \\
\hline & \multirow{3}{*}{$\mathrm{F}$} & \multicolumn{2}{|c|}{ Levene Varyans Eşitliği Testi } & \multicolumn{7}{|c|}{ Ortalamaların Eşitliği için t-testi } \\
\hline & & \multirow[b]{2}{*}{$\mathrm{p}$} & \multirow{2}{*}{$\mathrm{t}$} & \multirow{2}{*}{$\mathrm{Sd}$} & \multirow{2}{*}{$\begin{array}{c}p \\
\text { (iki yönlü) }\end{array}$} & \multirow{2}{*}{$\begin{array}{c}\text { Ortalama } \\
\text { Fark }\end{array}$} & \multirow{2}{*}{$\begin{array}{l}\text { Std. Hata } \\
\text { Farkı }\end{array}$} & \multicolumn{2}{|c|}{ 95\% Farkın Güven Aralığı } & \\
\hline & & & & & & & & Alt & Üst & \\
\hline \multirow{2}{*}{ ilktot } & Eşit varyanslar varsayıldı & 4,062 & ,045 & ,164 & 410 & 870 & 04812 & 29375 &,- 52932 & 62557 \\
\hline & Eșit varyanslar varsayılmadı & & & 163 & 392,421 & 870 & 04812 & 29492 &,- 53170 & 62795 \\
\hline
\end{tabular}

Tablo 3. Lisans programında ilk yardım dersi alma ve ilk yardım bilgilerinin incelenmesi

\begin{tabular}{|c|c|c|c|c|c|c|c|c|c|c|}
\hline \multicolumn{11}{|c|}{ Bağımsız Örneklemler için T Testi } \\
\hline \multirow{3}{*}{\multicolumn{2}{|c|}{$\mathrm{F}$}} & \multicolumn{2}{|c|}{ Levene Varyans Eşitliği Testi } & \multicolumn{7}{|c|}{ Ortalamaların Eşitliği için t-testi } \\
\hline & & \multirow[t]{2}{*}{$\mathrm{p}$} & \multirow[t]{2}{*}{$\mathrm{t}$} & \multirow[t]{2}{*}{ Sd } & \multirow{2}{*}{$\begin{array}{c}\mathrm{p} \\
\text { (iki yönlü) }\end{array}$} & \multirow{2}{*}{$\begin{array}{l}\text { Ortalama } \\
\text { Fark }\end{array}$} & \multirow{2}{*}{$\begin{array}{l}\text { Std. Hata } \\
\text { Farkı }\end{array}$} & \multicolumn{2}{|c|}{ 95\% Farkın Güven Aralığı } & \\
\hline & & & & & & & & Alt & Üst & \\
\hline \multirow[t]{2}{*}{ ilktot } & Eşit varyanslar varsayıldı & 50,191 & ,000 & 2,555 & 410 & 011 & 80447 & 31480 & 18564 & 1,42329 \\
\hline & Eşit varyanslar varsayılmadı & & & 2,139 & 170,323 & ,034 & 80447 & 37611 & 06203 & 1,54690 \\
\hline
\end{tabular}


manın ilk yardım bilgisi üzerinde bir etkisinin olup olmadığını test etmek için bağımsız örneklemler t-testi uygulanmıştır. Analiz sonucunda, ilk yardım dersi alma $(\mathrm{X}=19,36, \mathrm{SS}=2,39)$ ve almamanin $(\mathrm{X}=18,56, \mathrm{SS}=3,94)$ grupları arasında istatistiksel olarak anlamlı bir fark bulunmuştur $(\mathrm{t}(170,3)=2,14, \mathrm{p}=0.034)$. Bu sonuçlara göre, ilk yardım dersi alan katılımcıların ilk yardım bilgi düzeyleri ilk yardım dersi almayan katılımcıların ilk yardım bilgi düzeylerine göre daha pozitiftir ve anlamlı bir farklılık vardır (bkz. Tablo 3).

Herhangi bir kurumdan ilk yardım eğitimi alma ya da almamanın ilk yardım bilgisi üzerinde bir etkisinin olup olmadığını test etmek için bağımsız değişkenler t-testi uygulanmıştır. Analiz sonucunda, ilk yardım eğitimi alma $(X=19,47, S S=2,39)$ ve almamanin $(X=18,49$, $\mathrm{SS}=3,71)$ grupları arasında istatistiksel olarak anlamlı bir fark bulunmuştur $(\mathrm{t}(223,04)=2,91, \mathrm{p}=0.004)$. Bu sonuçlara göre, herhangi bir kurumdan ilk yardım eğitimi alan katılımcıların ilk yardım bilgi düzeyleri, ilk yardım eğitimi almayan katılımcıların ilk yardım bilgi düzeylerine göre daha pozitiftir ve anlamlı bir farklılık vardır (bkz. Tablo 4).

Elde edilen bulgular, öğretmen adaylarının ilk yardım hakkında sahip oldukları bilgilerinde anabilim dalı ve sınıfın etkili olmamasına karşın ilk yardım dersi ve eğitimi almanın etkisi olduğunu göstermektedir.

\section{TARTIŞMA VE SONUÇ}

$\mathrm{Bu}$ çalışmada Doğu Anadolu'daki bir üniversitenin Temel Eğitim Bölümü öğrencilerinin anabilim dalı, bulundukları sınıf, lisans programında ilk yardım dersi alma ve herhangi bir kurumdan ilk yardım eğitimi alma durumu değişkenlerine bakılarak ilk yardım bilgi düzeyleri incelenmiştir.

Anabilim dalı ve sınıfa göre ilk yardım konusunda bilgi puanları arasında istatiksel olarak anlamlı bir farklılık saptanmamıştır. Aynı şekilde, bulunulan sınıfın ilk yardım bilgi düzeyi üzerinde herhangi bir etkisinin olmadığı gözlenmiştir. Yapılan ANOVA testinde sınıf ile ilk yardım bilgi düzeyi arasında anlamlı bir farklılık saptanmamıştır. Birinci sınıf olup, ilk yardım bilgi düzeyi yüksek olan birçok öğretmen adayı bulunmaktadır. Bunun olası çeşitli nedenlerinden biri daha önce herhangi bir kurumdan alınmış olunan ilk yardım eğitimi olabilir. Aynı şekilde son sınıf olup ilk yardım bilgi düzeyi düşük olan birçok öğretmen adayı da bulunmaktadır. Bunun olası sebeplerinden biri lisans programında verilen ilk yardım dersinin teorik bilgi düzeyinde kalması, diğeri ise ilk yardım bilgisi ve deneyimine ilişkin KPSS'de çıkan soruların az olması olabilir.

Anabilim dalı ile ilk yardım bilgi düzeyi arasında anlamlı bir fark bulunmamıştır. Ancak Okul Öncesi Öğretmenliği anabilim dalının, Sınıf Öğretmenliği anabilim dalına göre ilk yardım bilgi düzeylerinin daha yüksek olduğu gözlenmiştir. Okul öncesinde yaş grubu, ilkokula göre küçüktür. Aynı zamanda, bu yaştaki çocuklar çok fazla hareketlidir. Bu hareketlilik, merak ve keşfetme duygusu ile birleşince ve okul öncesi eğitimin oyun temelli olduğu göz önünde bulundurulduğunda, bu yaş grubunun tehlikeli durumlarda kalma ihtimali yüksektir. Bütün bu faktörler, ilk yardım bilgisinin okul öncesi bölümü öğretmen adaylarınca daha çok önemsenmesinin sebepleri olarak belirtilebilir.

Lisans programında ilk yardım dersi ya da herhangi bir kurumdan ilk yardım eğitimi almış olma durumuna göre her iki bölüm öğrencilerinin ilk yardım konusundaki bilgi puanları arasında istatiksel olarak anlamlı bir farklılık saptanmıştır. Öğrenim gördükleri lisans programında ilk yardım dersi gören öğretmen adaylarının, ders görmeyen öğretmen adaylarına oranla bilgi puanlarının yüksek olduğu görülmüştür. Daha önce herhangi bir kurumdan ilk yardım eğitimi alan öğretmen adaylarının ilk yardım bilgi puanlarının da eğitim almayan öğretmen adaylarına oranla yüksek olduğu bulunmuştur. Benzer bulgular, Abelairas-Gómez vd., (2020); Aktaş vd. (2019), Byrne vd. (2012), Demir vd. (2017), Dinçer vd. (2000), K1zil vd. (2018), Özer (2018), Özpulat ve Bilgen Sivri (2013), Saruhan vd. (2018), Usta vd. (2017) çalışmalarında da görülmüştür.

Özer'in (2018) yapmış olduğu araştırmanın bulgularına göre, ilk yardım eğitimi alma durumlarının öğrencilerin ilk yardım konusundaki bilgi düzeylerinde anlamlı farklılığa sebep olduğu gözlenmiştir. Okulda veya okul dışında eğitim almış öğrencilerin ilk yardım bilgi düzeylerinin, eğitim almamış öğrencilerden anlamlı düzeyde daha yüksek olduğu bulunmuştur (Özer, 2018). Aynı şekilde, Dinçer vd. (2000) tarafından yapılan çalışmada okul öncesi öğretmenlerinin ilk yardım bilgi düzeyleri ölçülmüş, araştırmaya 138 okul öncesi öğretmeni dâhil edilmiştir. Çalışma sonucunda ilk yardım konusunda bilgi düzeylerinin ilk yardım eğitimi almış öğretmenlerin lehine olduğu tespit edilmiştir (Dinçer, Atakurt ve Şimşek, 2000). $\mathrm{Bu}$ araştırmaya ek olarak, Aktaş vd. (2019) yaptığı ve ilköğretim birinci ve ikinci kademe öğretmenlerinin ilk yardım bilgi düzeylerini araştırdıkları araştırmalarında

Tablo 4. Herhangi bir kurumdan ilk yardım eğitimi alma ve ilk yardım bilgilerinin incelenmesi

\begin{tabular}{|c|c|c|c|c|c|c|c|c|c|c|}
\hline \multicolumn{11}{|c|}{ Bağımsız Örneklemler için T Testi } \\
\hline \multirow{3}{*}{\multicolumn{2}{|c|}{$\mathrm{F}$}} & \multicolumn{2}{|c|}{ Levene Varyans Eşitliği Testi } & \multicolumn{7}{|c|}{ Ortalamaların Eşitliği için t-testi } \\
\hline & & \multirow[t]{2}{*}{$\mathrm{p}$} & \multirow[t]{2}{*}{$\mathrm{t}$} & \multirow[t]{2}{*}{ Sd } & \multirow{2}{*}{$\begin{array}{c}\mathrm{p} \\
\text { (iki yönlü) }\end{array}$} & \multirow{2}{*}{$\begin{array}{c}\text { Ortalama } \\
\text { Fark }\end{array}$} & \multirow{2}{*}{$\begin{array}{l}\text { Std. Hata } \\
\text { Farkı }\end{array}$} & \multicolumn{2}{|c|}{ 95\% Farkın Güven Aralığı } & \\
\hline & & & & & & & & Alt & Upper & \\
\hline \multirow[t]{2}{*}{ ilktot } & Eşit varyanslar varsayıldı & 35,735 & 000 & 3,248 & 410 & ,001 & 97737 & 30089 & 38589 & 1,56884 \\
\hline & Eşit varyanslar varsayılmadı & & & 2,906 & 223,037 & ,004 & 97737 & 33637 & 31450 & 1,64023 \\
\hline
\end{tabular}


da sonuçlar diğer çalışmalarla tutarlıdır. Öğretmenlerin \%67,7'sinin ilk yardım konusunda bilgi sahibi oldukları, bilgi sahibi olan öğretmenlerin ise \%41,3'ünün kurslardan bilgi edindikleri belirtilmiştir (Aktaş, Dereli, Yıldırım Sarf ve Yılmaz, 2019). Özpulat ve Bilgen Sivri (2013) nin yaptıkları çalışmada da ilk yardım eğitimi alan 28 öğretmenin \%53.6'sı ilk yardım ile ilgili bir kurs ya da eğitime katıldıklarını belirtmişler; araștırma sonucunda, diğer araştırma sonuçlarını destekler şekilde eğitim alan öğretmenlerin ilk yardım bilgi düzeylerinin, almayan öğretmenlerin puanlarına göre daha yüksek olduğu bulunmuştur (Özpulat ve Bilgen Sivri, 2013). Sonuç olarak öğretmenlerin bilgi düzeylerinin aldıkları eğitimle orantılı olarak arttığı ifade edilirken hizmet öncesi eğitime vurgu yapılmıştır. Hizmet öncesinde öğretmen adaylarının alacakları ilk yardım dersiyle bilgi düzeylerinin artacağı öngörülebilir.

Kızıl vd. (2018) tarafından yapılan araştırmada, çalışmaya katılan kişilerden eğitim düzeyleri yüksek olanların birçoğunun yanıtlarının doğru olduğu tespit edilmiştir. Eğitim düzeyi yüksek olan kişilerin bilgi puanlarıyla düşük olan kişilerin bilgi puanları arasında fark saptanmıştır. Ancak araştırmacılar, bulguları yorumladıklarında Türkiye'de sistemli temel ilk yardım eğitimi ile ilgili ciddi sorunlar olduğunu belirtmişlerdir. Sürücülerin, servis annesi ve şoförlerinin, öğretmenlerin, okullarda çalışan kişilerin ve emekli kişilerin de ilk yardım eğitimi almaları gerektiğini ifade etmişlerdir (Kızıl vd., 2018). Benzer şekilde, Demir vd. (2017) tarafından meslek yüksekokulu öğrencileriyle yapılan çalışmada öğrencilerin ilk yardım konusunda çoğunlukla doğru yanıtlar verdiği ama yanlış yanıtların da göz ardı edilebilecek kadar az olmadığı bulunmuştur. Çalışmada yanlış uygulamaların kazazedeye zarar vereceği dikkate alınarak insanların ilk yardım konusunda bilinçlendirilmesi gerektiği vurgulanmıştır. Bu sorunun en temel nedeninin verilen derslerin teorikte kalması, uygulamaya dayalı eğitimlerin sınırlı olması düşünülmüştür (Demir vd., 2017). Uygulamalı ilk yardım eğitiminin literatürde vurgulanmaya başlandığı 1960lı yılların başından günümüze değin çeşitli yöntemlerin etkililiği araştırılmıştır. Eisenburger ve Safar (1999), Safar vd. (1981) gibi araştırmacılar ilk yardım eğitiminin başlarında manken üzerinde uygulamalara yer vermiştir. Büyükbörklü vd. (2010)'nin Sınıf Öğretmenliği Anabilim Dalı öğrencileriyle yaptıkları deneysel çalışma, ilk yardım dersinin bilgisayar destekli öğretim; Sançar vd. (2009)'nin yürüttükleri çalışma, ilk yardım eğitiminin yaratıcı drama temelinde uygulamalarla yapılmasının etkililiğini göstermektedir.

Usta vd., ilk yardım uygulamalarında sahip olunan teorik ya da uygulamaya dönük bilgi düzeyine ek olarak bazı faktörlerin de etkili olduğunu belirtmişlerdir. 2017 yılında yaptıkları bir araştırmada müfredatında ilk yardım dersi olan Sivil Savunma ve İtfaiye Programı öğrencilerinin ilk yardım bilgisi düzeyinin, müfredatında ilk yardım dersi bulunmayan Ormancılık ve Orman Ürün- leri Programı öğrencilerine oranla ilk yardım bilgilerinin daha yüksek olduğunu bulmuşlardır. Diğer deyişle, ilk yardım eğitimi almış olmak ilk yardım konusunda sahip olunan bilgi seviyesini artırmaktadır. Ancak tek başına bilgi düzeyinin yüksekliği meslek eğitiminde yeterli görülmemekte, buna ek olarak ilk yardım farkındalığının yüksek olmasının da etkili olduğu belirtilmektedir (Usta vd., 2017). Gülmez Dağ (2018)'ın çalışması da bilgi düzeyi ile ilk yardım uygulama konusundaki öz yeterliliğin ancak uygulama temelli, sistemli ve titiz bir hizmet öncesi eğitimle geliştirilebileceğini göstermektedir.

Literatürde bulunan çalışmalarla paralellik gösteren bu çalışmada, araştırmaya dahil olan öğrencilerin ilk yardım dersi ya da ilk yardım eğitimi almaları durumuna göre ilk yardım konusundaki bilgi düzeylerinin anlamlı farklılık gösterdiği tespit edilmiştir. İlk yardım eğitimi almamış kişilerin ilk yardım uygulamasında bulunması doğru sonuçlar vermeyebilir. Bu nedenle özellikle bu durumlarla sık sık karşıya gelebilecek olan öğretmenlerin ilk yardım konusunda eğitimlere katılmış olmaları, daha bilinçli olmaları son derece önemlidir. İlk yardım temelli eğitim çalışmaları hizmet öncesi öğretmen eğitim programlarına dahil edilmeli, hizmet içi eğitimle de öğretmenlerin bilgi ve farkındalığı arttırılmaya çalışılmalıdır. Buna ek olarak, verilecek teorik bilgiler uygulamayla pekiştirilmeli, ne zaman ne yapması gerektiği konusunda öğrenmelerin kalıcılığı artırılmalıdır. Öğretmen adayları ve/veya öğretmenlere ilk yardım bilgileri ve uygulama düzeyleri konusunda geri dönüt verilmeli, eksik kalan bilgilerin fark edilerek giderilmesi sağlanmalıdır. Öğretmen ve öğretmen adaylarının yanında, toplumdaki yanlış bilgileri düzeltecek çalışmalar interdisipliner bakış açısıyla yapılmalı ve yapılacak çalışmalarda bu grubun aktif olarak görevlendirilmesi, etkin rol almaları sağlanmalıdır. İlk yardım, ilköğretim ya da ortaöğretim ders programlarına da, çocukların yaş ve gelişim düzeyleri dikkate alınarak kaynaştırılmalıdır.

Bu çalışma, Doğu Anadolu Bölgesindeki bir büyükşehirde yer alan üniversitenin Eğitim Fakültesi Temel Eğitim Bölümü öğretmen adaylarıyla sınırlıdır. Bu bağlamda, öğretmen adaylarının ilk yardım bilgi düzeylerine ilişkin yapılan araştırmalar, Türkiye'yi yansıtacak şekilde genişletilebilir. Bu sınırlılığa ek olarak bu çalışma, Temel Eğitim Bölümü öğretmen adaylarının bilgi düzeyleriyle sınırlıdır. Farklı öğretmen yetiştirme programlarında öğrenim gören öğretmen adaylarıyla yapılacak çalışmalarla, bütünsel bir bakış açısı ortaya çıkarabilir. Yine bu tür nicel ya da nitel araştırmaların örneklemini oluşturduğu meta analiz ya da meta sentez çalışmaları yapılabilir. $\mathrm{Bu}$ araştırma nicel bir tarama araştırması olup belirtilen örneklem ve evrenle sinırlıdır. Mevcut durumun ortaya konulmasının yanında, var olan duruma ilişkin derinlemesine bilgi edinmeyi sağlayacak nitel araştırmalar planlanabilir.

$\mathrm{Bu}$ araştırmayla birlikte, eğitimde kaza ve yaralanma- 
ların en yüksek oranda görülebildiği dönem olan temel eğitim dönemindeki (okul öncesi ve ilkokul birinci kademe; 3-10 yaş arası) çocuklarla çalışması ihtimali bulunan Doğu Anadolu Bölgesindeki bir üniversitede öğrenim gören öğretmen adaylarının ilk yardım bilgi düzeyi araştırılmıştır. İlk yardım eğitiminin 10 yaşından itibaren verilebileceği, okul ortamında karşılaşılacak herhangi bir kaza durumunda ilk müdahaleyi öğretmenin yapması gerekebileceği ve öğretmenlerin, çocukların önemli birer rol modeli oldukları göz önünde bulundurulduğunda, ülkemizin her bölgesinde hizmet öncesindeki var olan durumun ortaya konulmasının, öğretmen eğitimi programları planlanırken etkili bir kaynak sağlayacağı düşünülmektedir.

\section{Etik Kurul İzni}

Bu çalışma için etik kurul izni Van Yüzüncü Yıl Üniversitesi Sosyal ve Beşeri Bilimler Etik Kurulu'nun 16/11/2020 tarihli ve 2020/13-01 numaralı kararı ile alınmıștır.

\section{KAYNAKÇA}

Abelairas-Gómez, C., Carballo-Fazanes, A., Martínez-Isasi, S., López-García, S., Rico-Díaz, J. ve Rodríguez-Nú nez, A. (2020). Knowledge and attitudes on first aid and basic life support of pre- and elementary school teachers and parents. An Pediatr (Barc), 92, 268-276.

Akalın, D., Göktaş, E., Harzum, E., Karaodul, G. ve Çobanoğlu, N. (2008). Eğitimciler için eğitim rehberi: Ilk yardım modülleri (Sağlık Bakanlığı Yayın No.: 722). T. C. Sağlık Bakanlığı Sağlık Eğitimi Genel Müdürlüğü. http://www.llkyardim.org.tr/ dokumanlar/Saglik-Bakanligi-Ilk-Yardim2.pdf

Aktaş, B., Yılmaz, M., Dereli, F. ve Yıldırım Sarf, H. (2019). İlköğretim birinci ve ikinci kademe öğretmenlerinin ilk yardım bilgi düzeyi. SANKO Üniversitesi Sağılk Bilimleri Fakültesi, 5(1), 17-22. Doi:10.5222/jaren.2019.18894

Bollig, G., Wahlc , H. A. ve Svendsend, M. V. (2009). Primary school children are able to perform basic life-saving first aid measures. Resuscitation, 80, 689-692.

Bombacı, H., Ülkü K., Adıyeke, L., Kara S. ve Görgeç, M. (2008). Çocuk yaralanmaları nedenleri ve önlemler. Acta Orthopaedica et Traumatologica Turcica, 42(3), 166-173. https://www.aott.org.tr/Content/files/sayilar/433/Vol\%20 42\%2C\%20No\%203\%20(2008)\%20Pages\%20166-173\%20tr. pdf

Brazelton, T. B. (1992). Touchpoints: The Essential Reference. ABD: Perseus.

Büyükbörklü, A., Boynukara, Z. ve Bakırcı, H. (2010). Bilgisayar destekli sağlık bilgisi ve ilk yardım öğretiminin öğrenci başarısına etkisi. Erzincan Eğitim Fakültesi Dergisi, 12(1), 251-264.

Byrne, J., Speller, V., Dewhirst, S., Roderick, P., Almond, P., Grace, M. ve Memon, A. (2012). Health promotion in pre-service teacher education: Effects of a pilot inter-professional curriculum change. Health Education, 112(6), 525-542. Doi 10.1108/09654281211275872

Çatak, M. (2015). Ortaokullarda sosyal bilgiler öğretiminin öğretmen görüşlerine göre incelenmesi. Turkish Studies (Elektronik), 10(7), 259-316. Doi:http://dx.doi.org/10.7827/ TurkishStudies.8154
Demir Barutçu, C., Dilek, G. A., Çakmak, Ö., Köksoy, S. ve Polat, M. (2017, Eylül-Aralık). Level of knowledge and factors affecting first aid in vocational high school students. International Journal of Caring Sciences, 10(3), 1563-1568.

Dinçer, Ç., Atakurt, Y. ve Şimşek, I. (2000). Okul öncesi eğitimcilerinin ilk yardım bilgi düzeyleri üzerine bir araştırma. Ankara Üniversitesi Tıp Fakültesi Mecmuası, 53(1), 31-38. http://dspace.ankara.edu.tr/xmlui/bitstream/handle/20.500.12575/54554/10952.pdf?sequence=1\&isAllowe$d=y$

Eisenburger, P. ve Safar, P. (1999). Life supporting first aid training of the public-review and recommendations. Resuscitation, 41, 3-18.

Erkan, M. ve Göz, F. (2006). Öğretmenlerin ilk yardım konusundaki bilgi düzeylerinin belirlenmesi. Journal of Anatolia Nursing and Health Sciences, 9(4), 63-68. https://dergipark. org.tr/en/download/article-file/29336

Fazlığulları, O. ve Kurul, N. (2012). Türkiye'deki eğitim bilimleri doktora tezlerinin özellikleri. Mehmet Akif Ersoy Üniversitesi Eğitim Fakültesi Dergisi, 12(24), 43-75.http://hdl.handle. net/11672/181

Gülmez Dağ, G. (2018). Are tomorrow's teachers ready to save lives in cases of emergency? Elementary Education Online, 17(3), 1662-1671. doi 10.17051/ilkonline.2018.466413

Halk Sağlığı Genel Müdürlüğü (2019, 3-9 Eylül). Halk Sağlığı Haftası "Anne ve Çocuk Sağ/ı̆̆ı". [Basın bülteni]. https://hsgm. saglik.gov.tr/tr/haberler/halk-sagligi-haftasi-anne-ve-cocuk-sagligi.html

İnanç, Ç.D., Baysal, U.S., Coşgun, I., Taviloğlu, K. ve Ünüvar, E. (2008). Çocukluk çağı yaralanmalarında hazırlayıcı nedenler. Türk Pediatri Arşivi, 43(3), 84-88.

Kızıl, M., Üstünkarlı, N., Yıldız, Ş., Kurtel, K., Şermin, İ. ve Abacıoğlu, Y.H. (2018, Nisan). illk yardım bilgilerinin doğruluğu ve ilk yardım uygulamalarına etkisinin değerlendirilmesi. Hastane Öncesi Dergisi, 3(1), 15-30.https://dergipark.org.tr/ en/pub/hod/issue/36902/421554

Nayir, T., Uskun, E. ,Türkoğlu, H., Uzun, E., Öztürk, M. ve Kişioğlu, A. N. (2011). Isparta il merkezinde görevli öğretmenlerin ilk yardım bilgi düzeyleri ve tutumları. SDÜ Tıp Fakültesi Dergisi, 18(4), 123-7. https://dergipark.org.tr/ en/download/article-file/196920

Öz, Ş. S. (2010). 0-5 yaş grubu çocukların sağlık izlenimlerinde ev içinde ve ev dışında kaza risklerinin belirlenmesi (Uzmanlık Tezi). İstanbul Üniversitesi Çocuk Sağlığı Enstitüsü; İstanbul.

Özçelikay, G., Şimşek, I. ve Asil, E. (1996). Üniversite öğrencilerinin ilk yardım konusundaki bilgi düzeyleri üzerine bir çalışma. Ankara Üniversitesi Eczacılık Fakültesi Dergisi, 25(2), 43-8. http://dspace.ankara.edu.tr/xmlui/bitstream/ handle/20.500.12575/45404/12994.pdf?sequence=1\&isAllowed $=y$

Özer, Z. (2018). Öğretmen adaylarının ilk yardım konusunda bilgi düzeyleri (Yüksek Lisans Tezi). KKTC SağlıkBilimleri Enstitüsü; Lefkoşa. http://docs.neu.edu.tr/library/6715002735. pdf

Özpulat, F. ve Sivri, B. B. (2013). İlköğretim okullarında görev yapan öğretmenlerin ilk yardım bilgi düzeylerinin belirlenmesi. Aile Çocuk ve Eğitim Dergisi, 1(2), 15-16. https:// www.academia.edu/download/55236597/ilkogretim-okullarinda-gorev-yapan- ogretmenlerin-ilk-yardim-bilgi-du- 
zeylerinin-belirlenmesi201701.pdf

Safar, P., Berkebile, P., Scott, M. A., Esposito, G., Medsger, A., Ricci, E. ve Malloy, C. L. (1981, Mayıs). Education research on life-supporting first aid (LSFA) and CPR self-training systems (STS). Critical Care Medicine, 9(5), 403-404. doi: 10.1097/00003246-198105000-00026. PMID: 7214973.

Sançar, B., Açıkgöz, İ. ve Yalçın, A. S. (2009). İlk yardım eğitiminde yaratıcı drama yönteminin başarı üzerine etkisi. Yaratııı Drama Dergisi, 8(4), 81-97.

Saruhan, Ç., Saruhan, R., Yıldırım, C. ve Ovayolu, N. (2018). Gaziantep ili devlet ilköğretim okullarında çalışan öğretmenlerin ilk yardım uygulamasına ilişkin bilgi düzeylerinin belirlenmesi. Batman Üniversitesi Yaşam Bilimleri Dergisi, 8(1/2), 36-46. https://dergipark.org.tr/en/pub/buyasambid/issue/37496/381253

Sönmez, Y., Uskun, E. ve Pehlivan, A. (2014). Okul öncesi öğretmenlerinin temel ilk yardım uygulamalarına ilişkin bilgi düzeyleri, Isparta örneği. Türk Pediatri Araştırmaları, 49, 238-46. Doi:10.5152/tpa.2014.1581

Türkiye İstatistik Kurumu. (2020a, 24 Haziran). Ölüm ve Ölüm Nedeni İstatistikleri, 2019 [Basın bülteni]. https://data. tuik.gov.tr/Bulten/Index?p=Olum-ve-Olum-Nedeni-Istatistikleri-2019-33710

Türkiye İstatistik Kurumu. (2020b, Nisan). İstatistiklerle Çocuk 2020 (TÜiK Yayım No. 4614). https://data.tuik.gov.tr/Bulten/Index? $p=$ Istatistiklerle-Cocuk-2020-37228

Uğur Baysal, S., Yıldırım, F. ve Bulut, A. (2005). Çocuk güvenliği: Yaralanmalardan ve zehirlenmelerden korunma güvenlik kontrol listesi. İstanbul Tıp Fakültesi Kadın ve Çocuk Sağlığı Eğitim ve Araştırma Birimi. https://www.travma.org/ TravmaData/Document/2410201411201-2hAQ3RRoB1Lq. pdf

Umur, Y. F. (2012). Illk Yardım Kitabı. İstanbul: T.C. Aile ve Sosyal Politikalar Bakanlığı Aile ve Toplum Hizmetleri Genel Müdürlügü. https://www.aep.gov.tr/wp-content/uploads/2012/10/05_06_ilk-yardim.pdf

Usta, G., Küçük, U. ve Torpuş, K. (2017). Meslek yüksekokulu öğrencilerinin ilk yardım bilgi düzeyleri ve tutumlarının belirlenmesi. Hastane Öncesi Dergisi, 2(2), 67-77. https:// dergipark.org.tr/en/pub/hod/issue/31941/351620 